\title{
Speciation of chromium in beverages and seasoning samples by magnetic solid-phase extraction and microsample injection system flame atomic absorption spectrometry
}

\author{
Şükrü Gökhan ELÇі iD \\ Pamukkale University, Technology Faculty, Biomedical Engineering Department, 20017 Denizli-Turkey
}

\begin{abstract}
In this research, a magnetic solid phase extraction based on the use of magnetic polyanilinepolythiophene copolymer $\left(\mathrm{Fe}_{3} \mathrm{O}_{4} @\right.$ coPANI-PTH) nanoparticles is applied for chromium speciation from water, beverages and seasoning samples followed by microsample injection system-flame atomic absorption spectrometry(MIS-FAAS) analysis. The selective adsorption of $\mathrm{Cr}(\mathrm{III})$ in presence of $\mathrm{Cr}(\mathrm{VI})$ by $\mathrm{Fe}_{3} \mathrm{O}_{4} @$ coPANI-PTH in the pH range of 9.0-10.5 was obtained and the total $\mathrm{Cr}$, after reduction of chromium(VI) to chromium(III) by adding $0.5 \mathrm{~mL}$ of concentrated $\mathrm{H}_{2} \mathrm{SO}_{4}$ and $10 \mathrm{~mL}$ of $5 \%$ (w/v) hydroxylamine hydrochloride, was determined. The detection limit, enhancement factor, and repeatability of the optimized method for $\mathrm{Cr}$ (III) were calculated to be $1.5 \mu \mathrm{g} \mathrm{L}^{-1}, 38.5$, and $1.78 \%$, respectively. The method was validated by the analysis of TMDW-500 drinking water and LGC7162 Strawberry Leaves as certified reference materials. The relative error for total chromium was found to be lower than $4.6 \%$ Recoveries were obtained quantitatively using this method $(\geq 95 \%)$.
\end{abstract}

\section{Article info \\ History:}

Received:07.04.2020

Accepted:04.06.2020

Keywords:

$\mathrm{Fe}_{3} \mathrm{O}_{4} @$ coPANI-PTH, chromium, speciation, water, beverages.

\section{Introduction}

Chromium is one of the commonly employed elements in various industries, such as leather, textile, paint, battery, ceramic, glass, metal, catalyst, and fungicide[1,2]. Therefore, large amounts of chromium species are emitted or discharged to the environment as waste. This leads to the pollution of farmlands and the pollution of irrigation and drinking water resources. Then, these species are gradually taken up by plants and they reach the human's body through the food chain.

Chromium is typically found in the environment in two oxidation forms: trivalent chromium, $\mathrm{Cr}(\mathrm{III})$, and hexavalent chromium, $\mathrm{Cr}(\mathrm{VI})$. The naturally occurring $\mathrm{Cr}(\mathrm{III})$ is a less toxic and essential ion for the body and it plays a role in glucose and lipid metabolism[3,4]. While certain amounts of $\mathrm{Cr}$ (III) is essential, an excess amount of $\mathrm{Cr}(\mathrm{IIII})$ could create toxicity[3,4]. Then, this toxicity may cause some diseases such as cancer or damage to the nervous system[3,4]. On the contrary, $\mathrm{Cr}(\mathrm{VI})$ is highly toxic due to its carcinogenic and mutagenic properties[5,6]. Also, $\mathrm{Cr}(\mathrm{VI})$ is highly soluble and mobile in groundwater and surface water that could create problems for human health[7]. Thus,
EPA and WHO recommend the threshold value for total chromium as $100 \mu \mathrm{g} \mathrm{L}{ }^{-1}$ and $\mathrm{Cr}(\mathrm{VI})$ as $50 \mu \mathrm{g} \mathrm{L}^{-1}$ in drinking water, respectively[8,9]. Chromium is mostly found in meat, fruit, vegetables, grains, and legumes. $\mathrm{Cr}(\mathrm{VI})$ content in many food samples is less than the content of $\mathrm{Cr}$ (III)[10]. Taking into account the potential toxicity of $\mathrm{Cr}$ (III) and the high toxicity of $\mathrm{Cr}(\mathrm{VI})$, it is important to monitor their concentrations in various samples. In real samples, low concentrations of both chromium ions and the complexity of matrix make the determination of these ions challenging. For this reason, an accurate quantification method including preconcentration/separation procedure is required to develop for speciation studies[11].

It is well known that flame atomic absorption spectrometry(FAAS) is widely used for the determination of the total concentration of a metal ion in aqueous samples. Nevertheless, due to its low sensitivity, this technique is not used directly for the determination of total chromium. Also, it lacks ion selectivity for speciation of the different oxidation states of chromium. For overcoming these problems, the speciation analysis is required by combining FAAS with ion selective preconcentration method. Many chromium speciation methods coupled with FAAS 
such as solid phase extraction[12,13], coprecipitation[14,15], cloud point extraction (CPE) $[16,17]$ and dispersive liquid-liquid microextraction (DLLME)[18,19] have been developed to simplify analytical approaches. Among these, solid-phase extraction (SPE) based on column technique is generally found to be a more efficient one with high preconcentration factor, easy automation, and commonly available commercial solid phase materials. However, it has some drawbacks like time consuming processes, relatively complicated operation, and slightly toxic organic solvent use. These drawbacks of conventional SPE technique have been avoided by using nanostructured magnetic adsorbents and nowadays, magnetic solid phase extraction(MSPE) have become more popular in preconcentration studies. The magnetic adsorbents have advantages such as easy preparation procedures, faster adsorption and desorption properties, low-cost, environmental friendliness and high surface area that makes them effective adsorbent in SPE. Additionally, by an external magnetic field, the magnetic adsorbent can be simply removed from the analysis solution that it is added. The core-shell magnetic nanoparticles such as $\mathrm{Fe}_{3} \mathrm{O}_{4}, \gamma-\mathrm{Fe}_{2} \mathrm{O}_{3}$, and some ferrites $\left(\mathrm{MFe}_{2} \mathrm{O}_{4}(\mathrm{M}: \mathrm{Cu}\right.$, $\mathrm{Ni}, \mathrm{Mn}, \mathrm{Mg}$, etc.)) can be functionalized with various complexing agents on the particle surface to increase the specificity towards metal ions[20,21,22]. For this purpose, conductive polymers (CPs) with sulfur, oxygen, or nitrogen groups complexing with metal ions are promising for selective preconcentration of heavy metal ions without the need for any complexing agent[21]. Additionally, they are preferred due to their highly stable nature at different $\mathrm{pH}$ ranges, nontoxic properties, and rapid synthesis procedures. Various CPs, polyaniline(PANI) [23], polypyrrole(PPY) [24,25], polythiophene (PTH) [26,27] and their derivatives[28] have been applied in removal and preconcentration studies of heavy metal ions. In most of these works, only a single type of polymer is used except in a few examples copolymers such as PPYPTH, PANI-PPY, and so on are used [29-32]. According to the literature search, there is no report seen on the use of PANI-PTH copolymer coated $\mathrm{Fe}_{3} \mathrm{O}_{4}$ NPs $\left(\mathrm{Fe}_{3} \mathrm{O}_{4} @\right.$ coPANI-PTH) for chromium speciation.

Herein, I synthesized $\mathrm{Fe}_{3} \mathrm{O} 4 @$ coPANI-PTH nanoparticles and successfully applied them as a nanosorbent for the MSPE of chromium speciation in real samples. Following the speciation, MIS-FAAS was used for chromium detection.

\section{Materials and Methods}

\subsection{Instrumentation and apparatus}

A flame atomic absorption spectrometer (Perkin Elmer AAnalyst 200, Norwalk, CT, USA) equipped with a chromium hollow cathode lamp was used with a handmade microsample injection system (MIS) installed on it. The spectrometer was set as recommended in the manufacturer's manual. The MIS provides acceptable absorbance to be obtained with $100 \mu \mathrm{L}$ sample volume injected with a micropipette into the spectrometer nebulizer[14]. A pH meter (WTW pH720 model, Weilheim, Germany), a heating magnetic stirrer (Velp Scientifica ARE, Usmate, Italy), and an ultrasonic bath (Ultrasound Bendelin Electronic, Berlin, Germany) were used when necessary. The ultrapure (UP) quality water (resistivity, 18.2 M $\mathrm{cm}-1$ ) was obtained with the reverse osmosis system (Human Corp., Seoul, Korea).

\subsection{Reagents and solutions}

All reagents used in this work were at least analytical reagent grade. Ferric chloride $\left(\mathrm{FeCl}_{3} \cdot 6 \mathrm{H}_{2} \mathrm{O}\right.$, Sigma Aldrich, St. Louis, MO, USA), ferrous sulfate (FeSO ${ }_{4} \cdot 7 \mathrm{H}_{2} \mathrm{O}$, Panreac, Barcelona, Spain), aniline and thiophene (analytical grade, Merck, Darmstadt, Germany) were used in the synthesis of $\mathrm{Fe}_{3} \mathrm{O}_{4} @$ coPANI-PTH. Nitric acid (65\%,v/v), hydrochloric acid $(37 \%, \mathrm{v} / \mathrm{v})$, phosphoric acid $(85 \%)$, acetic acid(glacial), sodium hydroxide, ammonia solution $(25 \%)$ were purchased commercially (E. Merck, Darmstadt, Germany). Standard stock solutions of $\mathrm{Cr}$ (III) (LGC, Manchester, USA) and Cr(VI) (High Purity, North Charleston, USA) as 1000 $\mathrm{mg} \mathrm{L}^{-1}$, were used to prepare the daily test and calibration standard solutions. The $\mathrm{pH}$ adjustments of test and sample solutions were carried out using an $\mathrm{H}_{2} \mathrm{PO}_{4}{ }^{-} / \mathrm{H}_{3} \mathrm{PO}_{4}$ buffer to $\mathrm{pH} 2, \mathrm{CH}_{3} \mathrm{COO}^{-} / \mathrm{CH}_{3} \mathrm{COOH}$ buffers to $\mathrm{pH} 4-6$, with $\mathrm{H}_{2} \mathrm{PO}_{4}{ }^{-} / \mathrm{HPO}_{4}{ }^{2-}$ buffers to $\mathrm{pH}$ 6.5-7.5 and $\mathrm{NH}_{4}^{+} / \mathrm{NH}_{3}$ buffers to $\mathrm{pH} 8-11$.

Drinking water (TMDW-500) and Strawberry Leaves(LGC7162) were used to check the accuracy as the certified reference materials. The analyzed real samples were purchased from local markets in Denizli/Turkey.

\subsection{Synthesis of $\mathrm{Fe}_{3} \mathrm{O}_{4} @$ coPANI-PTH}

$\mathrm{Fe}_{3} \mathrm{O}_{4} @$ coPANI-PTH nanoparticles as a magnetic adsorbent were prepared via in-situ chemical oxidative polymerization of aniline and thiophene monomers by using $\mathrm{FeCl}_{3}$ in the presence of $\mathrm{Fe}_{3} \mathrm{O}_{4}$, by modifying the 
procedure from previous works [29,30-34]. The detail of the synthesis process and characterization data was reported in my earlier work [35]. However, after each synthesis of the magnetic copolymer, $\mathrm{Fe}_{3} \mathrm{O}_{4}$ and $\mathrm{Fe}_{3} \mathrm{O}_{4} @$ coPANI-PTH IR spectra recorded by ATR-IR instrument (UATR two model, PerkinElmer, Waltham, MA, USA) and the results were compared. Once the peaks belonging to $\mathrm{Fe}_{3} \mathrm{O}_{4}$-Polyaniline and $\mathrm{Fe}_{3} \mathrm{O}_{4}$ Polythiophene recognized in synthesized $\mathrm{Fe}_{3} \mathrm{O}_{4} @$ coPANI-PTH, these $\mathrm{Fe}_{3} \mathrm{O}_{4} @$ coPANI-PTH nanoparticles were used as magnetic solid phase throughout the study.

\subsection{General procedure using $\mathrm{Fe}_{3} \mathrm{O}_{4} @$ coPANI-PTH magnetic nanoparticles}

Particular volumes of $\mathrm{Cr}(\mathrm{III})$ solutions $(5-100 \mathrm{~mL})$ with concentrations from 10 to $100 \mu \mathrm{g} \mathrm{L}^{-1}$ were placed into a beaker and buffered to desired $\mathrm{pHs}$ in the range of 2-12.100 mg of $\mathrm{Fe}_{3} \mathrm{O}_{4} @$ coPANI-PTH nanoparticles was added into the beaker and the resulting mixture was shaken by hand for $5 \mathrm{~min}$ to ensure the quantitative extraction of $\mathrm{Cr}(\mathrm{IIII})$ ions by the nanosorbent. After that, by applying an external magnet, the liquid is discarded. The remaining magnetic nanoparticles loaded with $\mathrm{Cr}$ (III) at the bottom of the beaker were treated with $0.5-5.0 \mathrm{~mL}$ of $0.2 \%$ thiourea solution in a mixture of $2 \mathrm{~mol} \mathrm{~L}^{-1} \mathrm{HCl}$ and $1 \mathrm{~mol} \mathrm{~L}^{-1} \mathrm{HNO}_{3}$ and sonicated for $5 \mathrm{~min}$. Then, the $\mathrm{Fe}_{3} \mathrm{O}_{4} @$ coPANI-PTH nanoparticles were magnetically collected at the bottom of beaker, and the recovered $\mathrm{Cr}$ (III) ions in the clear solution were determined by a microsample injection system-flame atomic absorption spectrometry (MIS-FAAS) to investigate the adsorption behavior of the nanoparticles (Scheme 1).

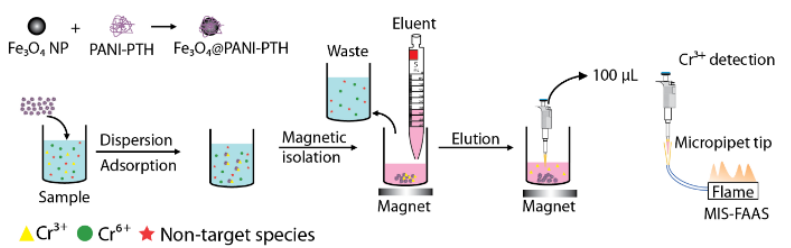

Scheme 1. Magnetic solid phase extraction of $\mathrm{Cr}(\mathrm{III})$ ions using $\mathrm{Fe}_{3} \mathrm{O}_{4} @$ coPANI-PTH

\section{5. $\operatorname{Cr}(\mathrm{III})$ and $\operatorname{Cr}(\mathrm{VI})$ determination in real samples}

The analyzed local beverages and seasoning samples were prepared according to a simplified and modified version of previous publications [36,37]. $0.6 \mathrm{~mL}$ conc. $\mathrm{HNO}_{3}$ was added to a $40 \mathrm{~mL}$ sample in a $50 \mathrm{~mL}$ centrifuge tube (Isolab, Eschau, Germany) and the tube was carefully shaken and then centrifuged for $10 \mathrm{~min}$ at $10,000 \mathrm{rpm}$ to remove solid particles. The acidic supernatant solutions were buffered to $\mathrm{pH} 10$ by adding conc. $\mathrm{NH}_{3}$ dropwise by controlling $\mathrm{pH}$ values with a $\mathrm{pH}$ meter. $\mathrm{Cr}$ (III) concentration in the buffered sample solution was determined by the general procedure presented in Section 2.4.

After reducing $\mathrm{Cr}(\mathrm{VI})$ to $\mathrm{Cr}(\mathrm{III})$ by adding $1.0 \mathrm{~mL}$ of concentrated $\mathrm{H}_{2} \mathrm{SO}_{4}$ and $5.0 \mathrm{~mL}$ of $5 \% \quad(\mathrm{w} / \mathrm{v})$ hydroxylamine hydrochloride[38,39,40], total chromium concentration $\left(\mathrm{Cr}_{\mathrm{T}}\right)$ was determined as $\mathrm{Cr}$ (III) by the procedure in Section 2.4. The given volumes of concentrated $\mathrm{H}_{2} \mathrm{SO}_{4}$ and $5 \%$ hydroxylamine hydrochloride were added into a $40 \mathrm{~mL}$ sample without any pretreatment in a $100 \mathrm{~mL}$ beaker and the solution was boiled for $30 \mathrm{~min}$. Then, the solution was cooled to room temperature, and the $\mathrm{pH}$ of the solution was adjusted to 10 by adding conc. $\mathrm{NH}_{3}$ dropwise. After $\mathrm{pH}$ adjustment, $\mathrm{Cr}_{\mathrm{T}}$ was determined following the procedure given in Section 2.4. The $\mathrm{Cr}(\mathrm{VI})$ concentration was calculated by subtracting concentration of $\mathrm{Cr}_{\mathrm{T}}$ from the concentration of $\mathrm{Cr}(\mathrm{III})$.

The dried and powdered LGC7162 Strawberry Leaves were weighed as $0.50 \mathrm{~g}$ into a beaker and treated with $4.0 \mathrm{~mL}$ of aqua regia for $3 \mathrm{~h}$ at $85^{\circ} \mathrm{C}$ on a hot plate to extract chromium species from the sample[38]. To remove undissolved parts, the resulting solutions were filtered through a filter paper. $0.5 \mathrm{~mL}$ of conc. $\mathrm{H}_{2} \mathrm{SO}_{4}$ and $10 \mathrm{~mL}$ of $5 \%(\mathrm{w} / \mathrm{v})$ hydroxylamine hydrochloride added filtrate were boiled for $30 \mathrm{~min}$ to ensure that $\mathrm{Cr}(\mathrm{VI})$ is completely reduced to $\mathrm{Cr}(\mathrm{III})[38,39,40]$. The final solution cooled to room temperature was buffered to $\mathrm{pH} 10$ by adding conc. $\mathrm{NH}_{3}$ dropwise and then the procedure given in Section 2.4 was followed to determine $\mathrm{Cr}_{\mathrm{T}}$.

\section{Results and Discussion}

\subsection{Effect of $\mathrm{pH}$}

A suitable $\mathrm{pH}$ can improve the efficiency and selectivity of adsorbent as it influences both the surface chemistry of adsorbent and the solution chemistry of chromium ions. So, the $\mathrm{pH}$ optimization of the analyzed solution is primarily performed in the development of speciation/preconcentration methods based on solid phase extraction. So, the effect of $\mathrm{pH}$ on the adsorption of $\mathrm{Cr}(\mathrm{III})$ and $\mathrm{Cr}(\mathrm{VI})$ ions was controlled over a $\mathrm{pH}$ range of 2 to 12 . The data in Figure 1 showed quantitative adsorption (recovery $\geq 95 \%$ ) of $\mathrm{Cr}(\mathrm{III})$ ions over the $\mathrm{pH}$ ranges of 9-10.5. At the same $\mathrm{pH}$ range, the recovery values for $\mathrm{Cr}(\mathrm{VI})$ ions were found to be $\leq 10 \%$. It was concluded that the suitable $\mathrm{pH}$ is 10 for distinguishing $\mathrm{Cr}(\mathrm{III})$ and $\mathrm{Cr}(\mathrm{VI})$ and this $\mathrm{pH}$ is chosen for the subsequent experiments. 


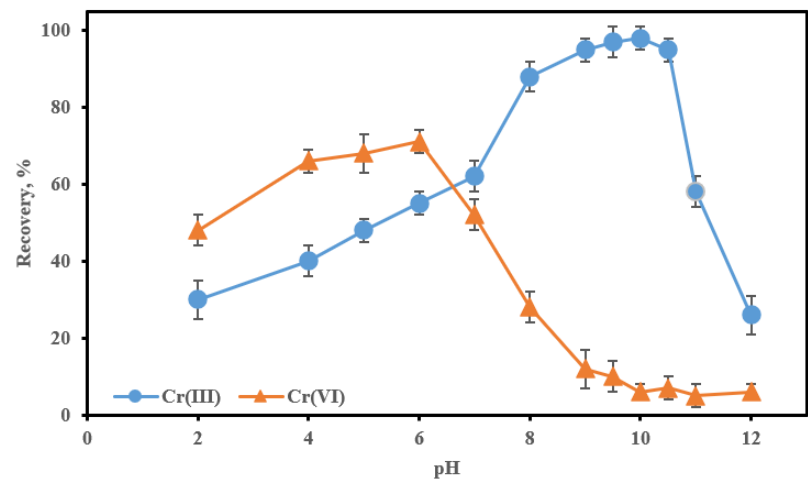

Figure 1. Effect of $\mathrm{pH}$ on recovery of $\mathrm{Cr}(\mathrm{III})$ and $\mathrm{Cr}(\mathrm{VI})$ ions using $100 \mathrm{mg} \mathrm{Fe}{ }_{3} \mathrm{O}_{4} @$ coPANI-PTH (n:3, Sample vol.: $40 \mathrm{~mL}$, Analyte conc.: $25 \mu \mathrm{g} \mathrm{L}{ }^{-1}$, Eluent vol.:2 mL )

The increase in the recovery of $\mathrm{Cr}(\mathrm{III})$ from $\mathrm{pH} 2$ to 8 can be explained by the deprotonation of nitrogen and sulfur atoms on the surface of $\mathrm{Fe}_{3} \mathrm{O}_{4} @$ coPANI-PTH. As a result of this deprotonation at $\mathrm{pH} 8$ and beyond, the complex formation can be achieved between $\mathrm{Cr}(\mathrm{III})$ species $\left(\mathrm{Cr}\left(\mathrm{H}_{2} \mathrm{O}\right)_{2}(\mathrm{OH})^{2+}\right.$ or $\left.\mathrm{Cr}\left(\mathrm{H}_{2} \mathrm{O}\right)(\mathrm{OH})_{2}{ }^{+}\right)$and the surface[41]. Below $\mathrm{pH} 8$, since the ions are positively charged and the surface is protonated, a repulsion of charges is present. The decrease in the recovery of $\mathrm{Cr}(\mathrm{VI})$ above $\mathrm{pH} 6$ can be explained by repulsion of $\mathrm{Cr}(\mathrm{IV})$ species due to the deprotonation of the surface[28]. Based on this behavior of the two chromium ions, $\mathrm{pH} 10$ was selected for the analysis.

\subsection{Effect of $\mathrm{Fe}_{3} \mathrm{O}_{4} @$ coPANI-PTH Amount}

The amount of adsorbent required to achieve efficient extraction is an important factor in preconcentration studies. Compared to the conventional adsorbents, the surface area of nanoparticle adsorbents is larger. Thus, quantitative recovery of analytes is expected to be achieved with a smaller amount of nanoparticle adsorbents. The influence of $\mathrm{Fe}_{3} \mathrm{O}_{4} @$ coPANI-PTH amount as a magnetic adsorbent on the recovery of $\mathrm{Cr}(\mathrm{III})$ at $\mathrm{pH} 10$ was investigated over the range of 50 to $200 \mathrm{mg}$ for preconcentration of $100 \mu \mathrm{g} \mathrm{L}^{-1} \mathrm{Cr}$ (III) from $20 \mathrm{~mL}$ solution. The quantitative recovery was obtained at 100 mg Fe $3 \mathrm{O}_{4} @$ coPANI-PTH (Table 1). A similar amount of nanoadsorbent use is recorded by other groups as well $[27,35,40]$. The low recoveries achieved below and above $100 \mathrm{mg}$ could possibly be attributed to the insufficient adsorbent amount and eluent volume, respectively.
Table 1. Effect of $\mathrm{Fe}_{3} \mathrm{O}_{4} @$ coPANI-PTH amount on extraction efficiency of $\mathrm{Cr}$ (III) (eluent: $2 \mathrm{~mL}$ of $0.2 \%$ thiourea solution prepared by $1 \mathrm{~mol} \mathrm{~L}^{-1} \mathrm{HNO}_{3}$ and $2 \mathrm{~mol}$ $\left.\mathrm{L}^{-1} \mathrm{HCl}, \mathrm{n}: 3\right)$

\begin{tabular}{cc}
\hline $\mathrm{Fe}_{3} \mathrm{O}_{4} @$ coPANI-PTH, mg & Recovery, $\%$ \\
\hline 50 & $44.9 \pm 6.5$ \\
75 & $82.3 \pm 4.1$ \\
100 & $96.0 \pm 4.3$ \\
125 & $65.5 \pm 7.5$ \\
200 & $58.7 \pm 2.0$ \\
\hline
\end{tabular}

\subsection{Sample volüme}

To attain a high preconcentration factor, it is important to work with a maximum sample volume that ensures quantitative adsorption of an analyte by an adsorbent. Effect of sample volume on the adsorption efficiency of $\mathrm{Cr}$ (III) ion was studied by extraction of the analytes from 10 to $100 \mathrm{~mL}$ of $100 \mu \mathrm{g} \mathrm{L}^{-1} \mathrm{Cr}$ (III) solution in the presence of $100 \mathrm{mg}$ of $\mathrm{Fe}_{3} \mathrm{O}_{4} @$ coPANI-PTH. The largest volume in which the quantitative recovery was obtained was found to be $80 \mathrm{~mL}$ (Table 2).

Table 2. Effect of varying sample volumes on recovery values of $\mathrm{Cr}$ (III) ions (eluent vol.: $2 \mathrm{~mL}, \mathrm{n}: 3$ )

\begin{tabular}{cc}
\hline Sample volume, $\mathrm{mL}$ & Recovery, \% \\
\hline 5 & $98.5 \pm 2.6$ \\
10 & $100.1 \pm 1.7$ \\
25 & $99.1 \pm 2.8$ \\
40 & $95.9 \pm 3.7$ \\
80 & $96.4 \pm 4.1$ \\
100 & $56.5 \pm 3.8$ \\
\hline
\end{tabular}

\subsection{Eluent type and volume}

From the data in Figure 1, it can be estimated that quantitative elution would be possible to attenuate the polythiophene-Cr(III) interaction using a highly acidic eluent. $\mathrm{Cr}(\mathrm{III})$ as a hard acid is well known to preferentially bind to nitrogen(hard acid) and sulfur(soft acid) containing ligands such as thiourea. Therefore, the eluation of preloaded $\mathrm{Cr}$ (III) from $\mathrm{Fe}_{3} \mathrm{O}_{4} @$ coPANI-PTH was controlled using $5.0 \mathrm{~mL}$ of thiourea solutions prepared with diluted $\mathrm{HCl}, \mathrm{HNO}_{3}$, and their mixtures(Table 3). The best elution efficiency was obtained with $0.2 \%$ thiourea in $1 \mathrm{M}$ $\mathrm{HNO}_{3}+2 \mathrm{M} \mathrm{HCl}$.

Table 3. Recoveries founded at various eluent volumes (sample vol.:40 mL, $100 \mu \mathrm{g} \mathrm{L}^{-1} \mathrm{Cr}(\mathrm{III}), \mathrm{n}: 3$ )

\begin{tabular}{cc}
\hline Eluent volumes, $\mathrm{mL}$ & Recovery, \% \\
\hline 5 & $95.3 \pm 3.6$ \\
2 & $97.1 \pm 4.1$ \\
1 & $67.2 \pm 3.3$ \\
0.5 & $58.9 \pm 3.8$ \\
\hline
\end{tabular}


To achieve the high preconcentration factor $(\mathrm{PF})$, the elution efficiency of smaller volumes of this eluent was examined over the range of 0.5 to $5 \mathrm{~mL} .2 .0 \mathrm{~mL}$ of $0.2 \%$ thiourea in $1 \mathrm{M} \mathrm{HNO}_{3}+2 \mathrm{M} \mathrm{HCl}$ provided the quantitative elution of $\mathrm{Cr}(\mathrm{III})$ as the smallest required eluent volume. The ratio of the maximum sample volume $(80 \mathrm{~mL})$ to minimum eluent volume $(2.0 \mathrm{~mL})$ defines the PF and based on that PF was calculated to be 40.0 .

\subsection{Extraction time for $\mathrm{Cr}$ (III)}

Another factor that requires to be optimized is the extraction time including adsorption and desorption times. Adsorption time is defined as the time required for complete adsorption of $\mathrm{Cr}$ (III) on the adsorbent surface. The effect of adsorption time was changed over the range of 2 to $15 \mathrm{~min}$ (Table 4). At $5 \mathrm{~min}$, the recovery values for $\mathrm{Cr}$ (III) achieved to be quantitative $(\geq 95 \%)$, after that there is no remarkable change in the recovery of $\mathrm{Cr}$ (III). This short time can be attributed to the attractive surface properties of the adsorbent for rapid adsorption of $\mathrm{Cr}(\mathrm{III})$ from solution under operating conditions. Hence, 5 min was chosen as the adsorption time. A similar study was carried out for desorption time (elution time) by fixing the adsorption time to $5 \mathrm{~min}$. It was also found to be $5 \mathrm{~min}$. This fast extraction time can be explained by the fast adsorption kinetic between the surface and the analyte.
Table 4. Recovery changes found with varying adsorption and desorption times (sample vol.:80 mL, eluent vol.: $2 \mathrm{~mL}$, Cr(III) conc.: $\left.100 \mu \mathrm{g} \mathrm{L}{ }^{-1}, \mathrm{n}: 3\right)$

\begin{tabular}{ccc}
\hline \multirow{2}{*}{ Time, $\min$} & \multicolumn{2}{c}{ Recovery, \% } \\
\cline { 2 - 3 } & Adsorption $^{\mathrm{a}}$ & Desorption $^{\mathrm{b}}$ \\
\hline 2 & $36.2 \pm 3.6$ & $42.2 \pm 4.2$ \\
4 & $85.7 \pm 4.1$ & $79.1 \pm 3.8$ \\
5 & $96.9 \pm 3.4$ & $97.7 \pm 3.2$ \\
10 & $98.9 \pm 3.9$ & $96.8 \pm 4.2$ \\
15 & $97.2 \pm 2.9$ & $96.2 \pm 3.6$ \\
\hline${ }^{\mathrm{a}}$ at fixed desorption time of 5 min. ${ }^{\mathrm{b}}$ at fixed adsorption time \\
of 5 min.
\end{tabular}

\section{6. $\mathrm{Cr}$ (III) and $\mathrm{Cr}_{\mathrm{T}}$ determination in sample solution}

The usability of described methods in Section 2.4 and 2.5 were checked for the determination of $\mathrm{Cr}$ (III) and total chromium $\left(\mathrm{Cr}_{\mathrm{T}}\right)$ in a solution mixed with $\mathrm{Cr}(\mathrm{III})$ and $\mathrm{Cr}(\mathrm{VI})(\mathrm{Table} 5)$. $\mathrm{Cr}(\mathrm{III})$ ions from the solution containing $\mathrm{Cr}(\mathrm{III})$ and $\mathrm{Cr}(\mathrm{VI})$ were quantitatively adsorbed on $\mathrm{Fe}_{3} \mathrm{O}_{4} @$ @ coPANI-PTH while $\mathrm{Cr}(\mathrm{VI})$ ions remained almost completely in the supernatant solution. On the other hand, $\mathrm{Cr}_{\mathrm{T}}$ was determined after the reduction of $\mathrm{Cr}(\mathrm{VI})$ to $\mathrm{Cr}(\mathrm{III})$ by adding $0.5 \mathrm{~mL}$ of concentrated $\mathrm{H}_{2} \mathrm{SO}_{4}$ and $10 \mathrm{~mL}$ of $5 \% \quad(\mathrm{w} / \mathrm{v})$ hydroxylamine hydrochloride to a $40 \mathrm{~mL}$ sample solution containing $\mathrm{Cr}(\mathrm{III})$ and $\mathrm{Cr}(\mathrm{VI})$ at different amounts. $\mathrm{Cr}_{\mathrm{T}}$ was quantitatively recovered. $\mathrm{Cr}(\mathrm{VI})$ amount was calculated by subtracting $\mathrm{Cr}$ (III) amounts from $\mathrm{Cr}_{\mathrm{T}}$ amounts.

Table 5. Determination of $\mathrm{Cr}(\mathrm{III})$ ions and total chromium in the mixture of $\mathrm{Cr}(\mathrm{III})$ and $\mathrm{Cr}(\mathrm{VI})$ ions (Sample volume:40 mL, eluent vol. $2 \mathrm{~mL}, \mathrm{n}: 3$ )

\begin{tabular}{cccccc}
\hline \multicolumn{3}{c}{ Added, $\mu \mathrm{g}$} & \multicolumn{3}{c}{ Found, $\mu \mathrm{g} ;$ Recovery\% } \\
\hline $\mathrm{Cr}(\mathrm{III})$ & $\mathrm{Cr}(\mathrm{VI})$ & $\mathrm{Cr}_{\mathrm{T}}$ & $\mathrm{Cr}(\mathrm{III})^{\mathrm{a}}$ & $\mathrm{Cr}(\mathrm{VI})^{\mathrm{b}}$ & $\mathrm{Cr}_{\mathrm{T}}{ }^{\mathrm{c}}$ \\
\hline 5 & 5 & 10 & $4.8 \pm 0.1 ; 96.0$ & $4.7 \pm 0.2 ; 94.0$ & $9.6 \pm 0.2 ; 96.0$ \\
5 & 20 & 25 & $4.7 \pm 0.1 ; 94.0$ & $19.5 \pm 0.2 ; 97.5$ & $24.2 \pm 0.2 ; 96.8$ \\
10 & 5 & 15 & $9.9 \pm 0.1 ; 99.0$ & $4.8 \pm 0.2 ; 96.0$ & $14.7 \pm 0.2 ; 98.0$ \\
20 & 5 & 25 & $19.9 \pm 0.4 ; 99.5$ & $5.0 \pm 0.4 ; 100.0$ & $24.9 \pm 0.2 ; 99.6$
\end{tabular}

${ }^{\mathrm{a}} \mathrm{Cr}(\mathrm{III})$ : Determined amount of $\mathrm{Cr}(\mathrm{III})$ in presence of $\mathrm{Cr}(\mathrm{VI}),{ }^{\mathrm{b}} \mathrm{Cr}(\mathrm{VI})$ : Amount of $\mathrm{Cr}(\mathrm{VI})$ ions founded by subtracting $\mathrm{Cr}$ (III) amount from $\mathrm{Cr}_{\mathrm{T}}$ amount. ${ }^{\mathrm{c}} \mathrm{Cr}$ : determined after reducing $\mathrm{Cr}$ (VI) to $\mathrm{Cr}$ (III) ions in sample solutions

\subsection{Analytical performance figures}

Analytical performance figures of the established MSPE method, combined with MIS-FAAS were evaluated under the optimum conditions ( $\mathrm{pH} 10.0,100$ mg of $\mathrm{Fe}_{3} \mathrm{O}_{4} @$ coPANI-PTH, $80.0 \mathrm{~mL}$ sample volume, $2 \mathrm{~mL}$ eluent volume and $10 \mathrm{~min}$ extraction time). The linear calibration equation in a range of 5-15 $\mu \mathrm{g} \mathrm{L}^{-1}$ was $\mathrm{A}=0.2272 \mathrm{C}_{\mathrm{Cr}(\mathrm{III})}-0.0009\left(\mathrm{R}^{2}=0.997\right)$, where $\mathrm{A}$ and $\mathrm{C}_{\mathrm{Cr}(\mathrm{III})}$ are the absorbance of chromium and concentration of chromium ion in $\mu \mathrm{g} \mathrm{L}^{-1}$, respectively. The established calibration equation without the preconcentration was $\mathrm{A}=0.0059 \quad \mathrm{C}_{\mathrm{Cr}(\mathrm{III})}-0.0003$ $\left(\mathrm{R}^{2}=0.996\right)$ in range of $0.2-5.0 \mu \mathrm{g} \mathrm{mL} \mathrm{m}^{-1}$ for $\mathrm{Cr}$ (III) ions. The enhancement factor (EF) was calculated to be 38.5 from the ratio of the slope of the calibration equation after preconcentration to that without preconcentration. The preconcentration factor(PF) was 40. The close PF and EF values confirm the accuracy of the method with the quantitative sorption and 
eluation cycle of the analyte recovered as $96.2 \%$ which is calculated as the ratio of the preconcentration factor to the enrichment factor. Nevertheless, the accuracy of the optimized method for real sample analysis was checked by applying to TMDW-500 drinking water and LGC7162 Strawberry Leaves as certified reference materials(Table 6). The student t-test was applied; the obtained $t_{\text {test }}$ values (1.667 for TMDW-500 and 2.474 for LGC7162) is lower than the $\mathrm{t}_{\text {critical }}=4.303$ (n:3 and 95\% confidence level); therefore, there is no significant difference between certified and found values, and the presented method is applicable for real sample analysis.

Table 6. Analysis of certificated reference materials using proposed method (TMDW-500 vol.: $50 \mathrm{~mL}$, LGC7162 Strawberry Leaves: $0.5 \mathrm{~g}, \mathrm{n}: 3$ )

\begin{tabular}{lccc} 
& & \multicolumn{2}{c}{$\begin{array}{c}\text { Total chromium conc., mean } \pm \\
\text { standard deviation }\end{array}$} \\
\cline { 2 - 4 } $\begin{array}{l}\text { Certified } \\
\text { reference } \\
\text { materials }\end{array}$ & Certified & Found & $\begin{array}{c}\text { Error, \%; } \\
\text { RSD, \% }\end{array}$ \\
\hline TMDW-500 & & & \\
Drinking water, & $20.0 \pm$ & $19.3 \pm$ & $-3.5 ; 3.1$ \\
$\mu$ L L $^{-1}$ & 0.1 & 0.6 & \\
Strawberry & $2.15 \pm$ & $2.05 \pm$ & $-4.6 ; 3.4$ \\
Leaves, $\mu \mathrm{g} \mathrm{g}^{-1}$ & 0.34 & 0.07 & \\
\hline
\end{tabular}

The reproducibility of the overall preconcentration method was calculated to be $1.85 \% \quad(n=7$,

Table 7. Analysis of water, fruit juice, soft drink and vinegar samples spiked with $\mathrm{Cr}(\mathrm{III})$ and $\mathrm{Cr}(\mathrm{VI})$ ions (n:3)

\begin{tabular}{|c|c|c|c|c|c|c|c|c|}
\hline \multirow[t]{2}{*}{ Samples } & \multicolumn{2}{|c|}{ Added, $\mu \mathrm{g} \mathrm{L}^{-1}$} & \multicolumn{3}{|c|}{ Found $^{\mathrm{a}}, \mu \mathrm{g} \mathrm{L}^{-1}$} & \multicolumn{3}{|c|}{ Recovery,\% } \\
\hline & $\mathrm{Cr}(\mathrm{III})$ & $\mathrm{Cr}(\mathrm{VI})$ & $\mathrm{Cr}(\mathrm{III})$ & $\mathrm{Cr}(\mathrm{VI})$ & $\mathrm{Cr}_{\mathrm{T}}$ & $\mathrm{Cr}(\mathrm{III})$ & $\mathrm{Cr}(\mathrm{VI})$ & $\mathrm{Cr}_{\mathrm{T}}$ \\
\hline \multirow{2}{*}{$\begin{array}{l}\text { Bottled } \\
\text { mineral } \\
\text { water }\end{array}$} & 0 & 0 & n.d. ${ }^{\mathrm{b}}$ & n.d. & n.d. & - & - & - \\
\hline & 50 & 50 & $50.4 \pm 3.7$ & $50.8 \pm 3.9$ & $101.2 \pm 1.2$ & 100.8 & 101.6 & 101.2 \\
\hline \multirow{2}{*}{$\begin{array}{l}\text { Spicy-turnip } \\
\text { juice }\end{array}$} & 0 & 0 & $8.6 \pm 0.8$ & $\leq \mathrm{LOQ}^{\mathrm{c}}$ & $9.4 \pm 0.6$ & - & - & - \\
\hline & 50 & 50 & $62.4 \pm 6.8$ & $48.6 \pm 9.9$ & $110.0 \pm 9.7$ & 107.6 & 97.2 & 100.6 \\
\hline \multirow{2}{*}{$\begin{array}{l}\text { Non-spicy } \\
\text { turnip juice }\end{array}$} & 0 & 0 & $10.5 \pm 1.2$ & $\leq \mathrm{LOQ}$ & $12.8 \pm 0.9$ & - & - & - \\
\hline & 50 & 50 & $60.8 \pm 0.8$ & $50.4 \pm 8.5$ & $111.2 \pm 3.8$ & 100.6 & 100.8 & 98.4 \\
\hline \multirow[t]{2}{*}{ Apple juice } & 0 & 0 & n.d. & n.d. & n.d. & - & - & - \\
\hline & 50 & 50 & $46.2 \pm 6.3$ & $48.2 \pm 6.6$ & $94.4 \pm 2.1$ & 92.4 & 96.4 & 94.4 \\
\hline \multirow{2}{*}{$\begin{array}{l}\text { Apple } \\
\text { vinegar }\end{array}$} & 0 & 0 & n.d. & n.d. & n.d. & - & - & - \\
\hline & 50 & 50 & $48.4 \pm 3.3$ & $50.8 \pm 4.1$ & $99.2 \pm 2.4$ & 96.8 & 101.6 & 99.2 \\
\hline \multirow{2}{*}{$\begin{array}{l}\text { Grape } \\
\text { vinegar }\end{array}$} & 0 & 0 & $14.3 \pm 3.6$ & $\leq \mathrm{LOQ}$ & $16.5 \pm 4.2$ & - & - & - \\
\hline & 50 & 50 & $64.1 \pm 3.5$ & $49.2 \pm 4.4$ & $113.3 \pm 3.7$ & 99.6 & 98.4 & 96.8 \\
\hline
\end{tabular}




\section{Conclusions}

The proposed magnetic solid phase extraction method for the preconcentration and speciation of chromium is simple, selective, and accurate. The recovery of $\mathrm{Cr}$ (III) from real samples and test solutions in the presence of $\mathrm{Cr}(\mathrm{VI})$ is quantitative at $\geq 95 \%$. The extraction time was fairly short as 10 minutes. Due to the use of $\mathrm{Fe}_{3} \mathrm{O}_{4} @$ coPANIPTH MNPs as adsorbent, $\mathrm{Cr}(\mathrm{III})$ ions were conveniently and rapidly collected on the adsorbent surface and then quickly desorbed from the adsorbent isolated with an external magnetic field. The method for selective determining $\mathrm{Cr}$ (III) revealed good analytical figures such as low LOD (1.5 $\left.\mu \mathrm{gL}^{-1}\right)$, high precision $(1.85 \%)$, and good preconcentration factor (40). Compared to the other research conducted in the literature, this method allows rapid extraction, low RSD, and comparable or higher PF [28,29,40,42-44]. Also, the figure of merits showed that the proposed MSPE-MIS-FAAS method was suitable for the rapid preconcentration, speciation, and determination of chromium in other beverages and various plant leaves.

\section{Acknowledgment}

The author thanks to Pamukkale University, Faculty of Art and Sciences, Chemistry Department, Analytical Chemsitry Research laboratory for allowing use of instrument and lab space.

\section{Conflicts of interest}

The authors state that did not have conflict of interests

\section{References}

[1] Dognani, G., Hadi P., Ma, H., Cabrera, F. C., Job, A. E., Agostini, D. L.S. and Hsiao, B. S. Effective chromium removal from water by polyaniline-coated electrospun adsorbent membrane. Chem. Eng. J., 372 (2019) 341-351.

[2] Rakhunde, R., Deshpande, L. and Juneja, H. D., Chemical Speciation of Chromium in Water: A Review. Crit. Rev. Env. Sci. Tec., 42(2012) 776810.

[3] Anderson, R.A, Chromium, glucose tolerance, diabetes and lipid metabolism. J. Advancement Med., 8 (1995) 37-49.

[4] Shirani, M., Salari, F., Habibollahi, S. and Akbari, A. Needle hub in-syringe solid phase extraction based a novel functionalized biopolyamide for simultaneous green separation/ preconcentration and determination of cobalt, nickel, and chromium(III) in food and environmental samples with micro sampling flame atomic absorption spectrometry. Microchem. J., 152 (2020) 340-347.

[5] Office of Dietary Supplements: National Institute of Health. (2013). Dietary Supplement Fact Sheet: Chromium. In).

[6] Hamilton, E.M., Young, S.D., Bailey, E.H. and Watts, M.J. Chromium speciation in foodstuffs: A review. Food Chem., 250 (2018) 105-112.

[7] Pan, C., Troyer, L.D., Liao, P., Catalano, J. G., Li, W. and Giammar, D. E. Effect of Humic Acid on the Removal of Chromium(VI) and the Production of Solids in Iron Electrocoagulation. Environ. Sci. Tech., 51 (2017) 6308-6318.

[8] US EPA. Report No. EPA/570/9-76/003; Washington, DC, 1976.

[9] Code of Federal Regulation. Protection of Environment. Section 141, 80, p. 425, 2011.

[10] Hernandez, F., Séby, F., Millour, S., Noël, L. and Guérin,T. Optimisation of selective alkaline extraction for $\mathrm{Cr}(\mathrm{VI})$ determination in dairy and cereal products by HPIC-ICPMS using an experimental design. Food Chem., 214 (2017) 339-346.

[11] Arain, M.A., Ali, I., Yilmaz, E. and Soylak, M. Nanomaterials based chromium speciation in environmental samples: A review. TracTrend Anal. Chem. 103 (2018) 44-55.

[12] Aksoy, E., Elci, S. G., Siyal, A. N. and Elci, L. Chromium speciation using an aminated amberlite XAD-4 resin column combined microsample injection-flame atomic absorption spectrometry. Acta Chim. Slov., 65 (2018) 512520.

[13] Sacmaci, S., Kartal, S. and Kumsuz, S. Chromium speciation in environmental samples by solid- phase extraction using lewatit ionac SR-7 resin and flame atomic absorption spectrometry. J. AOAC Int., 97 (2014) 17191724

[14] Baig, J. A., Hol, A., Akdogan, A., Arslan Kartal, A., Divrikli, U., Gul Kazi, T. and Elci, L. A novel strategy for chromium speciation at ultratrace level by microsample injection flame atomic absorption spectrophotometry. J. Anal. At. Spectrom., 27 (2012) 1509-1517.

[15] Karatepe, A., Korkmaz, E., Soylak, M. and Elci, L. Development of a coprecipitation system for the speciation/preconcentration of chromium in tap waters. J. Hazard. Mater., 173 (2010) 433437. 
[16] Matos, G.D., dos Reis, E.B., Costa, A.C.S. and Ferreira, S.L.C. Speciation of chromium in river water samples contaminated with leather effluents by flame atomic absorption spectrometry after separation/preconcentration by cloud point extraction. Microchem. J., 92 (2009) 135-139.

[17] Lu, J., Tian, J., Wu, H. and Zhao, C. Speciation determination of chromium(VI) and chromium(III) in soil samples after cloud point extraction. Anal. Lett., 42 (2009) 1662-1677.

[18] Shirkhanloo, H., Ghazaghi, M. and Mousavi, H. Z. Chromium speciation in human blood samples based on acetyl cysteine by dispersive liquid-liquid biomicroextraction and in-vitro evaluation of acetyl cysteine/cysteine for decreasing of hexavalent chromium concentration. J. Pharmaceut. Biomed., 118 (2016) 1-8.

[19] Hol, A., Arslan Kartal,A., Akdogan, A., Elci, A., Arslan,T. and Elci, L. Ion pair-dispersive liquidliquid microextraction coupled to microsample injection system-flame atomic absorption spectrometry for determination of gold at trace level in real samples. Acta Chim. Slov., 62 (2015) 196-203.

[20] Li, Y., Huang, L., He, W., Chen, Y. and Lou, B. Preparation of functionalized magnetic Fe3O4@Au@polydopamine nanocomposites and their application for copper(II) removal. Polymers, 10 (2018) 570-585.

[21] Hemmati, M., Rajabi, M. and Asghari, A. Magnetic nanoparticle based solid-phase extraction of heavy metal ions: A review on recent advances. Microchim. Acta, 185 (2018) 160.

[22] Yavuz, E., Tokalıoglu, S. and Patat, S. Coreshell $\mathrm{Fe} 3 \mathrm{O} 4$ polydopamine nanoparticles as sorbent for magnetic dispersive solid-phase extraction of copper from food samples. Food Chem., 263 (2018) 232-239.

[23] Rezvani, M., Asgharinezhad A.A., Ebrahimzadeh,H. and Shekari, N. A polyaniline-magnetite nanocomposite as an anion exchange sorbent for solid-phase extraction of chromium(VI) ions. Microchim. Acta, 181 (2014) 1887-1895.

[24] Abolhasani, J., Khanmiri, R.H, GhorbaniKalhor, E., Hassanpour, A., Asgharinezhad, A.A., Shekari, N. and Fathi, A. An Fe3O4@SiO2@polypyrrole_magnetic nanocomposite for the extraction and preconcentration of $\mathrm{Cd}(\mathrm{II})$ and $\mathrm{Ni}(\mathrm{II})$. Anal. Methods, 7 (2015) 313-320.
[25] Mehdinia, A., Asiabi, M. and Jabbari, A. Trace analysis of Pt (IV) metal ions in roadside soil and water samples by Fe3O4/graphene/polypyrrole nanocomposite as a solid-phase extraction sorbent followed by atomic absorption spectrometry. Intern. J. Environ. Anal. Chem., 95 (2015) 1099-1111.

[26] Tahmasebi, E. and Yamini, Y. Polythiophenecoated $\mathrm{Fe} 3 \mathrm{O} 4$ nanoparticles as a selective adsorbent for magnetic solid-phase extraction of silver(I), gold(III), copper(II) and palladium(II). Microchim. Acta, 181 (2014) 543-551.

[27] Elyas Sodan, N., Hol, A., Caylak, O. and Elci, L. Use of $\mathrm{Fe} 3 \mathrm{O} 4$ magnetic nanoparticles coated with polythiophene for simultaneous preconcentration of $\mathrm{Cu}$ (II), $\mathrm{Co}$ (II), $\mathrm{Cd}$ (II), $\mathrm{Ni}$ (II) and $\mathrm{Zn}$ (II) ions prior to their determination by MIS-FAAS. Acta Chim. Slov., 67, 2020, 375385.

[28] Hena, S. Removal of chromium hexavalent ion from aqueous solutions using biopolymer chitosan coated with poly 3-methyl thiophene polymer. J. Hazard. Mater., 181 (2010) 474479.

[29] Molaei, K., Bagheri, H., Asgharinezhad, A. A., Ebrahimzadeh, H. and Shamsipur, M. SiO2coated magnetic graphene oxide modified with polypyrrole-polythiophene: A novel and efficient nanocomposite for solid phase extraction of trace amounts of heavy metals. Talanta, 167 (2017) 607-616.

[30] Jalilian, N., Ebrahimzadeh, H., Asgharinezhad, A. A. and Molaei, K. Extraction and determination of trace amounts of gold(III), palladium(II), platinum(II) and silver(I) with the aid of amagnetic nanosorbent made from $\mathrm{Fe} 3 \mathrm{O} 4-$ decorated and silica-coated graphene oxide modified with a polypyrrolepolythiophene copolymer. Microchim. Acta, 184 (2017) 2191-2200.

[31] Kera, N.H., Bhaumik, M., Pillay, K. Ray, S.S. and Maity, A. Selective removal of toxic $\mathrm{Cr}(\mathrm{VI})$ from aqueous solution by adsorption combined with reduction at a magnetic nanocomposite surface. J. Colloid Interf. Sci., 503 (2017) 214228.

[32] Bhaumik, M., Arjun Maity, A., Srinivasu, V. V. and Onyango, M. S. Removal of hexavalent chromium from aqueous solution using polypyrrole-polyaniline nanofibers. Chem. Eng. J., 181(2012) 323-333.

[33] Martin, M., Salazar, P., Villalonga, R., Campuzano, S., Pingarron, J. M. and GonzalezMora, J. L. Preparation of core-shell Fe3O4@poly(dopamine) magnetic 
nanoparticles for biosensor construction. $J$. Mater. Chem. B, 2 (2014) 739-746.

[34] Liu, X., Ma, Z., Xing, J. and Liu, H. Preparation and characterization of amino-silane modified superparamagnetic silica nanospheres. J. Magn. Magn. Mater., 270 (2004) 1-6.

[35] Elci, S. G. A magnetic solid-phase extraction method using Fe3O4@coPANI-PTH for microsample injection system-flame atomic absorption spectrometric determination of nickel and copper in soft drinks and spice samples. Intern. J. Environ. Anal. Chem., Published (2020) DOI: 10.1080/03067319.2020.1747615.

[36] [36] Szymczycha-Madeja A. and Welna, M. Evaluation of a simple and fast method for the multi-elemental analysis in commercial fruit juice samples using atomic emission spectrometry. Food Chem., 141 (2013) 34663472.

[37] Elci, S. G., Yan, B., Kim, S. T., Saha, K., Jiang, Y., Klemmer, G. A., Moyano, D. F., Yeşilbag Tonga, G., Rotello, V. M. and Vachet, R. W. Quantitative imaging of $2 \mathrm{~nm}$ monolayerprotected gold nanoparticle distributions in tissues using laser ablation inductively-coupled plasma mass spectrometry (LA-ICP-MS). Analyst, 141 (2016) 2418-2425.

[38] [38] Tuzen, M., Determination of heavy metals in soil, mushroom and plant samples by atomic absorption spectrometry. Microchem. J., 74 (2003) 289-297.

[39] F. Aydın (Supervisor:Mustafa Soylak), Preconcentration of some heavy metal ions by using coprecipitation and solid phase extraction methods, PhD Thesis, Erciyes University, Graduate School of Natural and Applied Sciences, (2008), Kayseri, Türkiye.
[40] Elyas Sodan, N., Elci, S. G., Arslan Kartal, A., Hol, A. and Elci, L. Chromium speciation in food, biological and environmental samples using magnetic polythiophene nanoparticles, followed by microsample injection systemflame atomic absorption spectrometric determination. Microchemical Journal, Under review, 2020.

[41] Peng, H., Zhang, N., He, M., Chen, B., Hu, B. Simultaneous speciation analysis of inorganic arsenic, chromium and selenium in environmental waters by 3-(2aminoethylamino) propyltrimethoxysilane modified multi-wall carbon nanotubes packed microcolumn solid phase extraction and ICPMS. Talanta, 131 (2015) 266-272.

[42] K.M.Diniz, C.R.T.Tarley, Speciation analysis of chromium in water samples through sequential combination of dispersive magnetic solid phase extraction using mesoporous amino functionalized $\mathrm{Fe} 3 \mathrm{O} 4 / \mathrm{SiO} 2$ nanoparticles and cloud point extraction, Microchem. J., 123 (2015) 185-195.

[43] M. Manoochehri, L.A. Naghibzadeh, Nanocomposite based on dipyridylamine functionalized magnetic multiwalled carbon nanotubes for separation and preconcentration of toxic elements in black tea leaves and drinking water, Food Anal. Methods, 10(2017)1777-1786.

[44] M.Babazadeh, R. Hosseinzadeh-Khanmiri, J. Abolhasani, E. Ghorbani-Kalhor, A. Hassanpour, A. Solid phase extraction of heavy metal ions from agricultural samples with the aid of a novel functionalized magnetic metalorganic framework. RSC Advances, 5(2015) 19884-19892. 